\title{
Hastanede yatan çocukların hemşire algısının resim çizme yöntemi ile incelenmesi: Projektif araştırma
}

\author{
Gülzade Uysal1, Duygu Sönmez Düzkaya² , Gülçin Bozkurt ${ }^{3}$ Yağmur Çöplü ${ }^{4}$ \\ 10kan Üniversitesi, Sağlık Bilimleri Fakültesi, Hemşirelik Bölümü, İstanbul \\ 2İstanbul Üniversitesi, İstanbul Tıp Fakültesi, Hemş. Hiz. Müd., İstanbul \\ 3İstanbul Üniversitesi, Sağlık Bilimleri Fakültesi, Ebelik Bölümü, İstanbul \\ ${ }^{4}$ Kozyatağı Acıbadem Hastanesi, Yenidoğan Hemşiresi, Kozyatağı, İstanbul
}

Öz

Amaç: Araştırma, resim çizme yöntemini kullanarak hastaneye yatan çocuklarda hemşire algısını belirlemek amacıyla yapıldı. Yöntem: Tanımlayıcı özellikteki araștırmada, nicel veriler ve resim çizdirme yöntemi kullanılarak çocukların hemşire algısı irdelenmiştir. Araştırma bir üniversite hastanesinin çocuk sağlığı ve hastalıkları kliniğinde, Ekim 2016-Mayıs 2017 tarihlerinde gerçekleştirildi. Araştırmada örneklem seçimine gidilmemiş olup verilerin toplanması için ayrılan sürede, hastanede yatmakta olan 3-12 yaş arasında çalışmaya katılmaya istekli 264 çocuk araştırmanın örneklemini oluşturuldu. Veriler araştırmacılar tarafından hazırlanan "Soru formu" ve çocuklara verilen beyaz bir A4 kağıt ve boya kalemleri kullanarak elde edildi. Çalışma sonucunda elde edilen veriler tanımlayıcı istatistiksel yöntemler ve çizilen resimlerde tematik tümevarım analiz yöntemleri kullanılarak değerlendirildi. Bulgular: Çalışma grubundaki çocukların yaş ortalamasının 7.36 \pm 2.57 yıl, \%50.8'inin erkek olduğu ve \%57.6'sının kronik hastalık nedeniyle hastanede yattığı saptandı. Çocukların \%76.1'inin resimlerinde hemşireyi insan figürü olarak çizdiği, \%85.5'inin hemşireyi kadın olarak alglladığı ve 1/3'ünün (\%33.7) hemşireyi olumsuz algıladığı belirlendi. Çocukların yaş, cinsiyet, hastanede yatma nedenleri, anne ve babalarının öğrenim durumlarının hemşire algılarını etkilemediği görüldü ( $p>0.05)$. Sonuç: Hemşireler, çocukların gelişim düzeyine göre, sözel yöntemlerin yanı sıra resim çizme yöntemini; çocukların hemşire ve diğer sağlık profesyonellerinden beklentilerini, algılarını, hastane ve tedaviye ilişkin korku ve kaygıları belirlemek amacı ile kullanabilir.

Anahtar kelimeler: Çocuk, resim çizme, hastane, hemşire

Yazının geliş tarihi: 20.09.2017

Yazının kabul tarihi: 05.02.2018

Sorumlu yazar: Dr. Ögr. Üyesi Gülzade Uysal, Okan Üniv., Sağlık Bil. Fak., Hemşirelik Bölümü, Öğretim Üyesi, Akfirat-Tuzla 34959/İstanbul

Tel: 0216-6771630-3847

E-posta:gulzade.uysal@okan.edu.tr 


\title{
Investigation of the nursing perception of children in hospital with drawing method: Projective research
}

\begin{abstract}
Aim: There search was conducted in order to determine the nursing perception of the children in hospital by using the method of drawing pictures. Method: In the descriptive study, nurse perception of children was examined by using quantitative data an dimage drawing method. The research was implemented in a child's health and illness clinic of a university hospital from October 2016 to May 2017. No sample selection was made in the survey and 264 children who were willing to participate in the study between the ages of 3 and 12 in the hospital, were included in the study sample. The data were obtained using a "questionnare form" prepared by the researchers and a white paper and crayons given to the children. The data obtained in the study was evaluated using descriptive statistical methods and thematic induction analysis methods in drawnimages. Results: It is found that, the mean age of the children in the study group was $7.36 \pm 2.57$ years, $50.8 \%$ were male and $57.6 \%$ were hospitalized due to chronic illness. It was determined that $76.1 \%$ of the children painted the nurse as a human figure in the pictures, $85.5 \%$ perceived the nurse as a woman and $1 / 3(33.7 \%)$ perceived the nurse a negatively. It was seen that the age, gender, reasons for staying in the hospital, the educational status of the parents did not affect the nurse perceptions ( $p>0.05)$. Conclusion: Nurses, in addition to verbal methods, according to the level of development of children, can use to determine the expectations and perceptions of children from nurses and other health professionals with their fears and concerns about hospital and treatment.
\end{abstract}

Keywords: Child, drawing, hospital, nurse

\section{Giriş}

Hastaneye yatmanın çocukları psikolojik, fizyolojik ve bilișsel yönden etkilediği, kaygı ve endişelerini arttırdı ğı, bağımsızlıklarını engellediğ $\mathrm{i}$

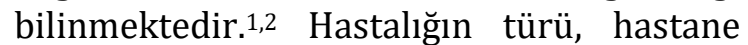
ortamı, yapılacak uygulamalar ve tedavi ekibinin tepkisine göre hastaneye yatmanın çocuk ve ailedeki etkisi değişmektedir.3,4,5 Hastane ortamı, yapılan girişimler ve sağlık çalışanları hakkında deneyimi olmayan çocuklar anksiyete, depresyon ve agresyon yaşamaktadır.5,6 Şen Beytut ve ark. (2009) ${ }^{5}$ hastanede izlenen 9-12 yaş arasındaki çocukların çizdikleri resimlerde; depresyon, anksiyete, agresyonu sı yansittıklarını saptamıştır.

Çocuklar resim çizerken kendilerine özgü ifadeler ile çizim yapmakta ve farklı yönlerini gösterebilmektedir.5,7 Güven (2009) ${ }^{8}$ çocukların çizdikleri resimlerle psikolojik durumlarını, kişilerarası ilişkilerini ve çeşitli duygularını sergilediğini ve iç dünyalarını yansıttığını bildirmektedir. Malchiodi (2001) ${ }^{9}$, çocuklar ile etkileşimde resmin bir iletişim aracı olduğunu, resim yapmanın çocuğu rahatlattığı ve güven duygusunu geliştirdiğini belirtmektedir. Dolayısıyla hastane gibi yabancı ortamlarda çocukların duygularını ifade etmesi için resim çizdirme yöntemi kullanılabilir. ${ }^{10,11}$

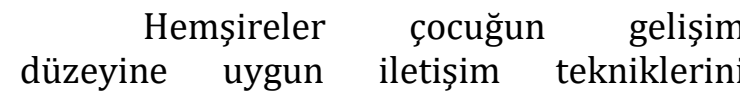
kullanabilmelidir. Çocukların duygularını ifade etmelerinde kolay ve yalın bir yöntem olan resim çizdirmenin kullanılması ile çocuk ve hemşire arasında daha güçlü bağların oluşabileceği bildirilmektedir.11,12 Resim çocuğun sorunlarına, güçlü ya da rahatsız edici deneyimlerine dair veri sağlamasının yanı sıra çocukların kendileri, çevreleri hakkındaki duygu ve düşüncelerini, algılarını fantezilerini ve gözlemlerini paylaşma firsatı sağlar. ${ }^{12}$ Resim çizdirme yolu ile elde edilen veriler hemşireler tarafından; çocuklardan sorunlarını belirleme, gelişim düzeyine uygun iletişim kurma ve uygun yaklaşımda bulunmak için kullanılabilir.1,8,13-15 Aynı zamanda hastaneye yatan çocukların fiziksel, sosyal ve psikolojik tepkileri ve hemşirelere yönelik algılarının belirlenmesi, hemşirenin çocuk ve aileye yaklaşımlarını gözden geçirme olanağı sağlayacaktır.5,15 
Araştırma, resim çizme yöntemini kullanarak hastanede yatan çocuklarda hemşire algısını belirlemek amacıyla yapıldı.

\section{Yöntem}

Tanımlayıcı özellikteki araştırmada, nicel veriler resim çizdirme yöntemi kullanılarak çocukların hemşire algısı irdelendi. Projektif bir yöntem olarak kabul edilen resim çizdirme yöntemi çocukların duygularını ve algılarını anlamlandırmak için psikologlar tarafından da sık kullanılmaktadır.5,12

Araştırma bir üniversite hastanesinin çocuk sağlığı ve hastalıkları kliniğinde, Ekim 2016-Mayıs 2017 tarihlerinde gerçekleștirildi. Verilerin toplanması için ayrılan sürede her hafta Perşembe günleri kliniğe gidilerek veriler elde edildi.

Araştırmanın evren ve örneklemi:
Araștırmanın yürütüldüğü çocuk sağlığı ve hastalıkları kliniğinde yatan 3-12 yaş arasındaki çocuklar oluşturdu. Araştırmanın yürütüldüğü klinikte iki çocuk servisi bulunmakta olup toplam 53 yatak vardır. Servislerde 22 hemşire, 7 uzman ve 8 asistan doktor çalışmaktadır. Çocuk Sağlığı ve Hastalıkları Kliniğine çocuklar birçok farklı kronik ve akut hastalık tanısı ile kabul edilmektedir. Her iki servisin de kendine ait birer oyun odası ve ailelerin kullanımına açık mutfakları bulunmaktadır. Çocuk ve Yenidoğan Yoğun Bakım ünitelerinde yatan hastalar örneklem dışında bırakılmıștır. Araştırmada örneklem seçimine gidilmemiş olup verilerin toplanması için ayrılan sürede, hastanede yatmakta olan iletişim kurulabilen, resim çizebilecek beceriye sahip, 3-12 yaş arasında çalışmaya katılmaya istekli 264 çocuk araştırmanın örneklemini oluşturdu. Araştırmaya katılmayı red eden 13 çocuk araştırma dışında birakıldı.

Veri toplama araçları: Veriler araştırmacılar tarafından hazırlanan "Soru formu" ve çocuklara verilen beyaz bir A4 kağıt ve boya kalemleri kullanarak elde edildi. Soru formunda çocuk ve ebeveyne ilişkin sosyodemografik özellikleri içeren 17 soru yer aldı ve yanıtlar ebeveynlerden alındı.
Çocuk sağlığı ve hastalıkları kliniğinde yatan çocuklara boş beyaz bir A4 kağıt ve 12 renk boya kalemi verilerek "hemşire" denilince akıllarına ilk gelen şeyleri çizmeleri istendi. Araştırmacılar biri tarafından resmi tamamlayan çocuklara çizdiği resim ile ilgili " Resimde kimler var?", "Ne yapıyorlar?", "Nasil davranıyorlar?", "Ne söylüyor?" gibi sorular soruldu. Çocukların çizdikleri resimler ile ilgili açıklamalar/yorumları soru formuna araştırmacılar tarafından kayıt edildi. Çocukların çizdiği resimler ve yapmış oldukları açıklamalar çizimleri yaptıran aynı iki araştırmacı tarafından tematik olarak analiz edilerek olumlu ve olumsuz hemşirelik algısı başlıkları altında katagorize edildi. Çalışma bulgularında çocukların resimlerine ve yaptıkları açıklamalara örnekler verildi.

Veri analizi ve yorumlama: Çalışma sonucunda elde edilen veriler SPSS 21.0 paket programında tanımlayıcı istatistiksel analizler; sayı, yüzde, ortalama, standart sapma, min-max, ki kare yöntemleri ile değerlendirildi. Çizilen resimler ise tümevarım analiz yöntemi kullanılarak değerlendirildi.

Patton (2002)'a göre tümevarım analiz yöntemi çocukların sembolik dünyasını anlamada araştırmaya önemli katkılar sağlamaktadır. Tümevarım analiz, kodlama yoluyla verilerin kategorilere ayrılması, kategoriler arasındaki ilişkileri çıkararak tema ve alt temalar oluşturmasıdır. $\mathrm{Bu}$ araştırmada ayrı bir uzmanlık gerektiren bir alan olması nedeniyle çocukların resimlerde yansıttığı gelişim özelliklerine göre irdeleme yapılması amaçlanmamıştır. Çocukların çizdikleri resimlerine yönelik sorulan sorulara verdikleri yanıtlar doğrultusunda, iki uzman tarafından değerlendirilerek "olumlu hemşirelik algıları" ve "olumsuz hemşirelik algıları" șeklinde iki kategoriye ayrıld. Çocuklardan resimleri yorumlamaları istenmiş ve açıklamaları resim kağıdına not alınmıştır. Sevgi dolu, iyileştiren, kurtaran, yardım eden, oyun oynatan, güler yüzlü, iyi insan, melek gibi, çiçek gibi, eğlenceli, arkadaş gibi, doğum günü kutlar, güzel, süslü, kahraman vb. ifadeler olumlu algılar olarak kabul 
edilmiştir. İğne yapan, can acıtan, ilaç veren, ağlatan, korkutan, kızgın, sinirli, sus yapar, susturur vb. ifadeler olumsuz alglar olarak kabul edilmiştir.

Araştırmanın etik yönü: Veri toplama öncesinde Okan Üniversitesi Etik Kurulundan gerekli izinler (Etik kurul no:77) alınmıştır. Veri toplama aşamasında, tüm ebeveynlere çalışmanın amacı hakkında bilgi verilerek sözlü ve yazılı onamları alınmıștır. Resimlerin tematik analizleri yapılırken çocukların isimleri kullanılmamış, rakamlar ile kodlanmıştır.

\section{Bulgular}

$\mathrm{Bu}$ bölümde hastanede yatan çocukların ve ebeveynlerinin tanıtıcı özellikleri, hemşirelik algılarına ilişsin nicel veriler ve çocukların çizimlerine yer verilmiştir.

Çocuk ve ebeveynlere ilişkin tanıtıcı özellikler Tablo 1'de verildi. Çalışma grubundaki çocukların yaş ortalamasının 7.36 \pm 2.57 yll, \%50.8'inin erkek, \%81.8'inin çekirdek ailede yaşadığı ve \%95'inin sosyal güvencesinin olduğu belirlendi. Çocukların hastanede yatış nedenleri incelendiğinde; \%57.6'sının kronik hastalık (kanser, diyabet, kistik fibrozis, astım vd.), $\% 42.4$ 'ünün ise akut bir hastalık (ishal, ateș, apandisit vd.) nedeniyle hastanede yattığı görüldü (Tablo 1).

Ebeveynlere ilişkin özellikler incelendiğinde; annelerin ortalama 33.30ะ6.19 yaşında olduğu, \%48.9'unun ilkokul-ortaokul mezunu olduğu ve \%67'sinin ev hanımı olduğu saptandı. Babaların ise ortalama $37.42 \pm 6.20$ yaşında, \%36'sının ilkokul-ortaokul mezunu olduğu ve \%94.3'ünün çalıştığı belirlendi (Tablo 1).

Çocukların hemşirelik algılarına ilişkin veriler Tablo 2'de yer almaktadır. Çocukların \%76.1'inin resimlerinde hemşire çizdiği, \%85.5'inin hemşireyi kadın olarak algıladığ $\quad$ (Şekil 5'te çocuk çizdiği resmi "Hastanede hemşire ve doktorlar var. Hemşireler kız, büyük çizdiğim erkek olan da doktor" şeklinde açlklamış) ve \%23.9'unun hemşireye ilişkin düşüncelerini anlatırken resimde hemşire yerine başka semboller (yıldız, kalp, enjektör vd.) kullandığı belirlendi (Tablo 2).

Çocukların resimlerindeki hemşireyi \%66.3'ünün olumlu (sevgi dolu, iyileștiren, yardım eden, oyun oynatan, güler yüzlü, iyi insan, melek, çiçek gibi) algıladığı ve \%33.7'sinin ise olumsuz (iğne yapan, can acıtan, ilaç veren, ağlatan, korkutan, kızgın) şeklinde algıladığı görüldü (Tablo 2).

Çocukların olumlu algıları için seçilen örneklerden Resim 1'de: "Elinde zürafa ile gezen güler yüzlü bir hemșire çizdim. Bir yıldız çizdim, hastanede güvende ve huzurlu olduğumu anlatıyor", Resim 2'de "Hemșireler bizi her sabah ziyaret ediyor, durumumuzu değerlendiriyor. Hep yanımızdalar bizi yalnız bırakmıyorlar" şeklinde açıklama yapmıştır.

Çocukların resimlerindeki olumsuz hemşire algısına örnek olarak seçilen Resim 3'de: "Hastaneye babamla gelmek istiyorum, ama serviste babaların kalması yasak. Serviste bizimle ilgilenen sarı saçl çok sinirli bir hemşire var. Resim 4'de: 'Hemşire ve iğne çizdim. Hemşire deyince aklıma iğne geliyor, hemşire odaya girdiğinde ağliyorum" şeklinde çizdiği resmi yorumladığı saptandı. Bir diğer çocuk ise çizdiği resmi, Resim 5: "Hastanede hemşire ve doktorlar. Hemşireler kız, büyük çizdiğim erkek olan da doktor" olarak yorumlamıştır.

Araștırmaya katılan çocukların ve ailelerin özellikleri ile çocukların resimlerde yansıttığı hemşire algilarının karşılaştırmasına tablo 3'te yer verildi. Çocukların yaş gruplarına göre olumlu ve olumsuz algıları karşılaştırıldığında, en fazla 3-6 yaş grubundaki çocukların olumsuz algı ifade ettikleri ancak gruplar arasındaki farkın istatistiksel olarak anlamlı olmadığ görüldü $(p>0.05)$. Çocukların cinsiyetlerine göre hemşire algıları incelendiğinde, kız çocuklarının daha fazla olumsuz algı bildirdiği, gruplar arasındaki farkın istatistiksel olarak anlamlı olmadığı saptand $\quad(p>0.05)$. Çocukların hastanede kronik veya akut hastalık nedeni ile yatıyor olmalarının hemşire algılarını etkilemediği belirlendi $(p>0.05)$. Çocukların anne ve babalarının öğrenim durumlarının çocukların hemşire algılarını etkileyen bir özellik olmadığı görüldü ( $p>0.05)$ (Tablo3). 
Tablo 1. Çocuk ve ebeveynleri tanıtıcı özellikler $(n=264)$

\begin{tabular}{|c|c|c|}
\hline Özellikler & $n$ & $\%$ \\
\hline \multicolumn{3}{|l|}{ Çocuk yaş } \\
\hline 3-6 yaş & 111 & 42.0 \\
\hline 7-12 yaş & 153 & 58.0 \\
\hline \multicolumn{3}{|l|}{ Çocuk cinsiyet } \\
\hline $\mathrm{K} 1 \mathrm{Z}$ & 130 & 49.2 \\
\hline Erkek & 134 & 50.8 \\
\hline \multicolumn{3}{|c|}{ Çocuğun hastanede yatma nedeni } \\
\hline Kronik hastalık & 152 & 57.6 \\
\hline Akut hastalık & 112 & 42.4 \\
\hline \multicolumn{3}{|l|}{ Kardeşinin olması } \\
\hline Var & 169 & 64.0 \\
\hline Yok & 95 & 36.0 \\
\hline \multicolumn{3}{|l|}{ Aile tipi } \\
\hline Çekirdek aile & 216 & 81.8 \\
\hline Geniş aile & 48 & 18.2 \\
\hline \multicolumn{3}{|l|}{ Anne öğrenim durumu } \\
\hline İlkokul- ortaokul mezunu & 129 & 48.9 \\
\hline Lise mezunu & 81 & 30.7 \\
\hline Üniversite mezunu & 54 & 20.5 \\
\hline \multicolumn{3}{|l|}{ Anne çalışma durumu } \\
\hline Çalışan & 87 & 33.0 \\
\hline Çalışmayan & 177 & 67.0 \\
\hline \multicolumn{3}{|l|}{ Baba öğrenim durumu } \\
\hline İlkokul- ortaokul mezunu & 95 & 36.0 \\
\hline Lise mezunu & 84 & 31.2 \\
\hline Üniversite mezunu & 85 & 32.2 \\
\hline \multicolumn{3}{|l|}{ Baba çalışma durumu } \\
\hline Çalışan & 250 & 94.7 \\
\hline Çalışmayan & 14 & 5.3 \\
\hline Çocuk yaş ortalaması & $7.36 \pm 2.57$ & \\
\hline Anne yaş ortalaması & $33.30 \pm 6.19$ & \\
\hline Baba yaş ortalaması & $37.42 \pm 6.20$ & \\
\hline
\end{tabular}


Tablo 2. Çocukların çizdiği resimlerdeki hemşire algıları (n=264)

\begin{tabular}{|c|c|c|}
\hline Özellikler & $n$ & $\%$ \\
\hline \multicolumn{3}{|c|}{ Resimlerde hemşire varlığ $(n=264)$} \\
\hline Var & 201 & 76.1 \\
\hline Yok & 63 & 23.9 \\
\hline \multicolumn{3}{|c|}{ Resimlerde hemşirelerin cinsiyetleri $(n=201)$} \\
\hline Kadın & 172 & 85.5 \\
\hline Erkek & 29 & 14.5 \\
\hline \multicolumn{3}{|c|}{ Çocukların resimlerdeki algıları } \\
\hline \multicolumn{3}{|l|}{ Olumlu algllar $(n=175)$} \\
\hline Sevgi dolu & 53 & 30.3 \\
\hline İyileştiren, kurtaran & 42 & 24.0 \\
\hline Yardım eden & 18 & 10.3 \\
\hline Oyun oynatan & 18 & 10.3 \\
\hline Güler yüzlü & 14 & 8.0 \\
\hline İyi insan & 13 & 7.4 \\
\hline Melek gibi & 7 & 4.0 \\
\hline Çiçek gibi & 4 & 2.3 \\
\hline Diğer ${ }^{1}$ & 6 & 3.4 \\
\hline \multicolumn{3}{|l|}{ Olumsuz algılar ( $n=89)$} \\
\hline İğne yapan, can acıtan & 54 & 60.7 \\
\hline İlaç veren & 14 & 15.7 \\
\hline Ağlatan & 8 & 9.0 \\
\hline Korkutan & 6 & 6.7 \\
\hline Kızgın, sinirli & 4 & 4.5 \\
\hline Diğer² & 3 & 3.4 \\
\hline
\end{tabular}

${ }^{1}$ Eğlenceli, arkadaş gibi, doğum günü kutlar, güzel, süslü, kahraman ${ }^{2}$ Sus yapar, susturur 
Tablo 3. Çocuklar ve ebeveynlerin özellikleri ile resimlerdeki hemşirelik algılarının karşılaştırılması ( $\mathrm{n}=264)$

\begin{tabular}{|c|c|c|c|c|c|}
\hline \multirow[b]{3}{*}{ Özellikler } & \multirow{2}{*}{\multicolumn{2}{|c|}{$\begin{array}{c}\text { Olumlu Algı } \\
\mathrm{n}=175\end{array}$}} & \multirow{2}{*}{\multicolumn{2}{|c|}{$\begin{array}{c}\text { Olumsuz Algı } \\
n=89\end{array}$}} & \multirow[b]{3}{*}{ Test / p } \\
\hline & & & & & \\
\hline & $\mathrm{n}$ & $\%$ & $\mathrm{n}$ & $\%$ & \\
\hline \multicolumn{6}{|l|}{ Çocuk yaş } \\
\hline 3- 6 yaş & 68 & 38.9 & 43 & 48.3 & \multirow{2}{*}{ 0.09* } \\
\hline 7-12 yaş & 107 & 61.1 & 46 & 45.7 & \\
\hline \multicolumn{6}{|l|}{ Çocuk cinsiyet } \\
\hline $\mathrm{Klz}$ & 80 & 45.7 & 50 & 56.2 & \multirow{2}{*}{${ }^{-}$} \\
\hline Erkek & 95 & 54.3 & 39 & 43.8 & \\
\hline \multicolumn{6}{|c|}{ Hastanede yatma nedeni } \\
\hline Akut & 79 & 45.1 & 33 & 37.1 & \multirow{2}{*}{$\begin{array}{c}- \\
0.237^{*}\end{array}$} \\
\hline Kronik & 96 & 54.9 & 56 & 62.9 & \\
\hline \multicolumn{6}{|l|}{ Anne-öğrenim durumu } \\
\hline İlk-ortaokul mezunu & 83 & 47.4 & 46 & 51.7 & \multirow{3}{*}{$\begin{array}{l}1.096 \\
0.578\end{array}$} \\
\hline Lise mezunu & 53 & 30.3 & 28 & 31.5 & \\
\hline Üniversite mezunu & 39 & 22.3 & 15 & 16.8 & \\
\hline \multicolumn{6}{|l|}{ Baba-öğrenim durumu } \\
\hline İlk-ortaokul mezunu & 59 & 33.7 & 36 & 40.4 & \multirow{3}{*}{$\begin{array}{l}1.909 \\
0.385\end{array}$} \\
\hline Lise mezunu & 55 & 31.4 & 29 & 32.6 & \\
\hline Üniversite mezunu & 61 & 34.9 & 24 & 27.0 & \\
\hline
\end{tabular}

Chi square test, *Fisher exact test 


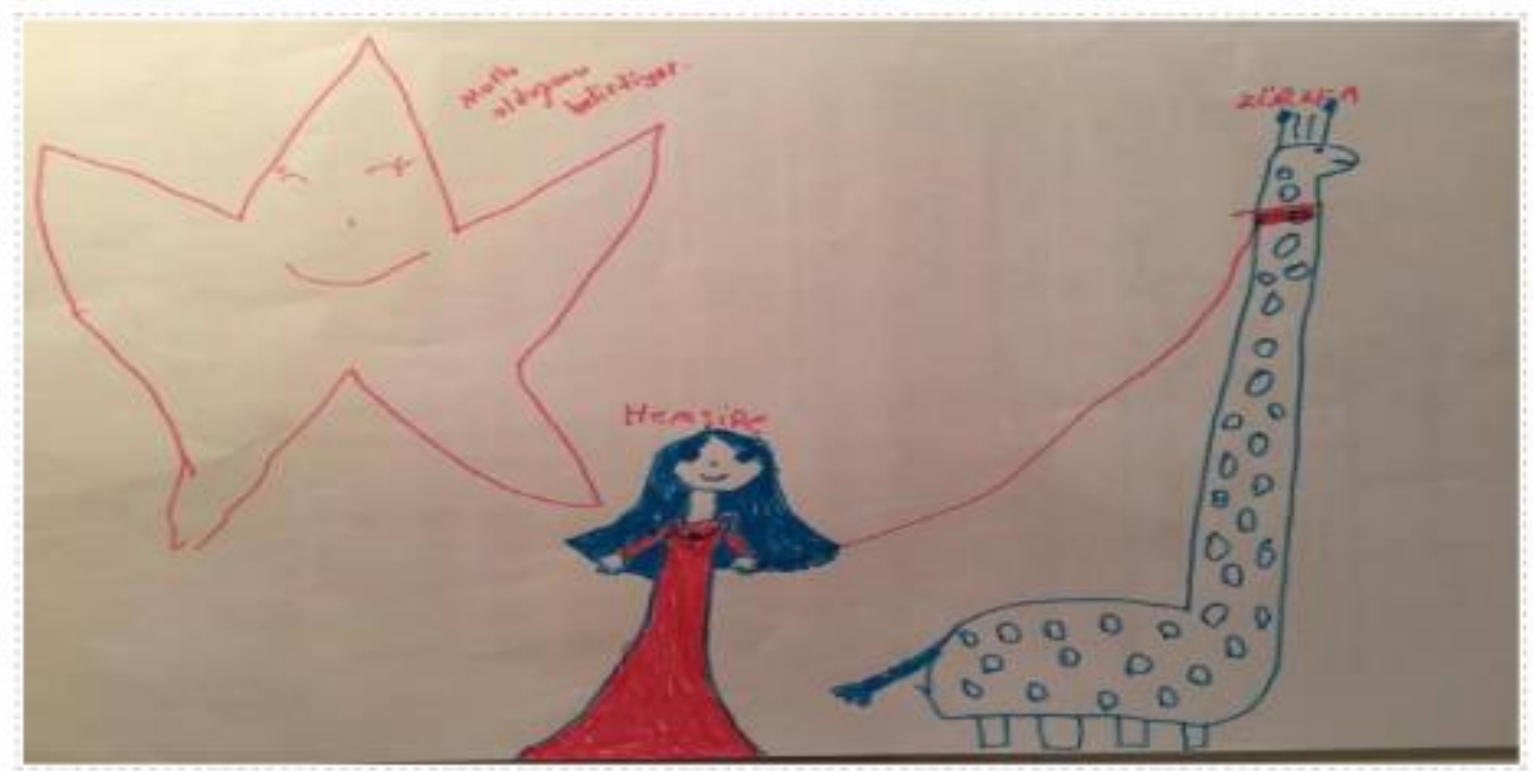

Resim 1. (Kod 215) "Elinde zürafa ile gezen güler yüzlü bir hemşire çizdim. Bir yıldız çizdim, hastanede güvende ve huzurlu olduğumu anlatıyor."

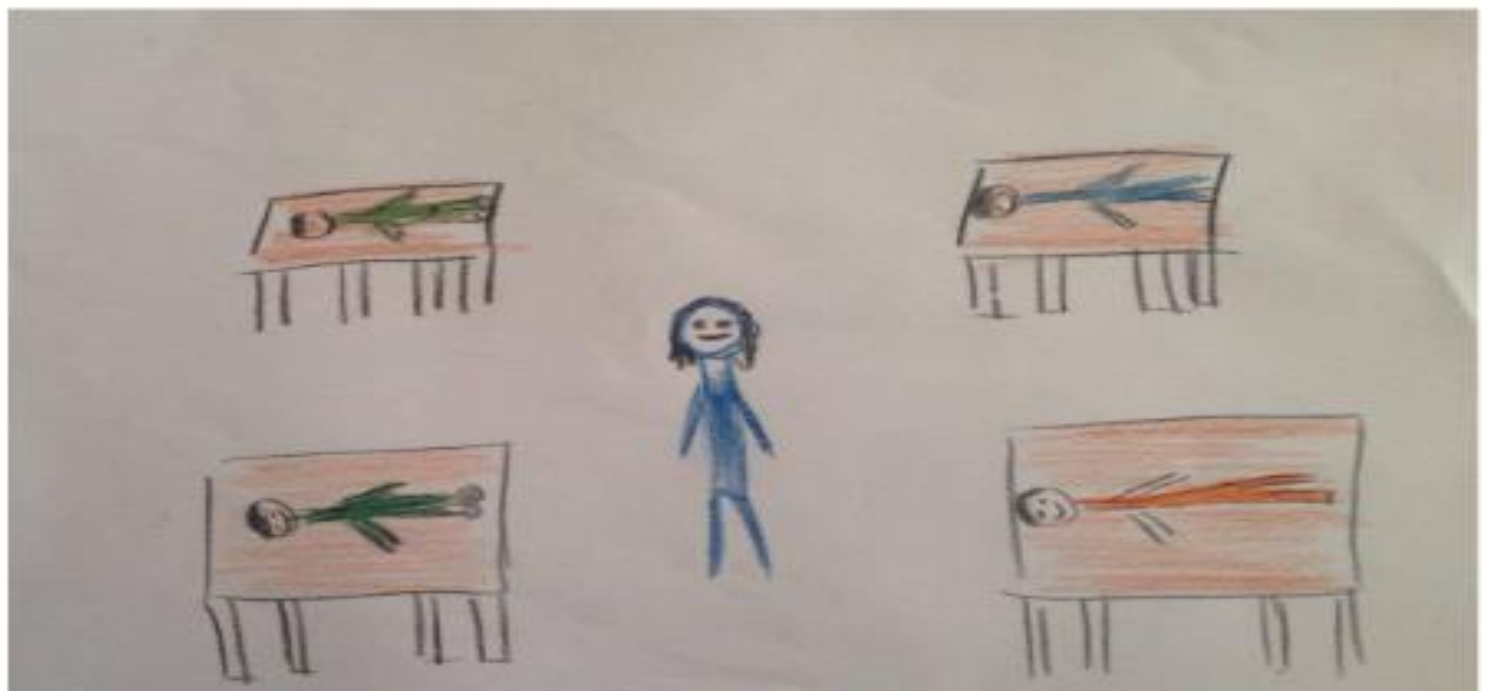

Resim 2. (Kod 229) "Hemşireler bizi her sabah ziyaret ediyor, durumumuzu değerlendiriyor. Hep yanımızdalar bizi yalnız bırakmıyorlar." 


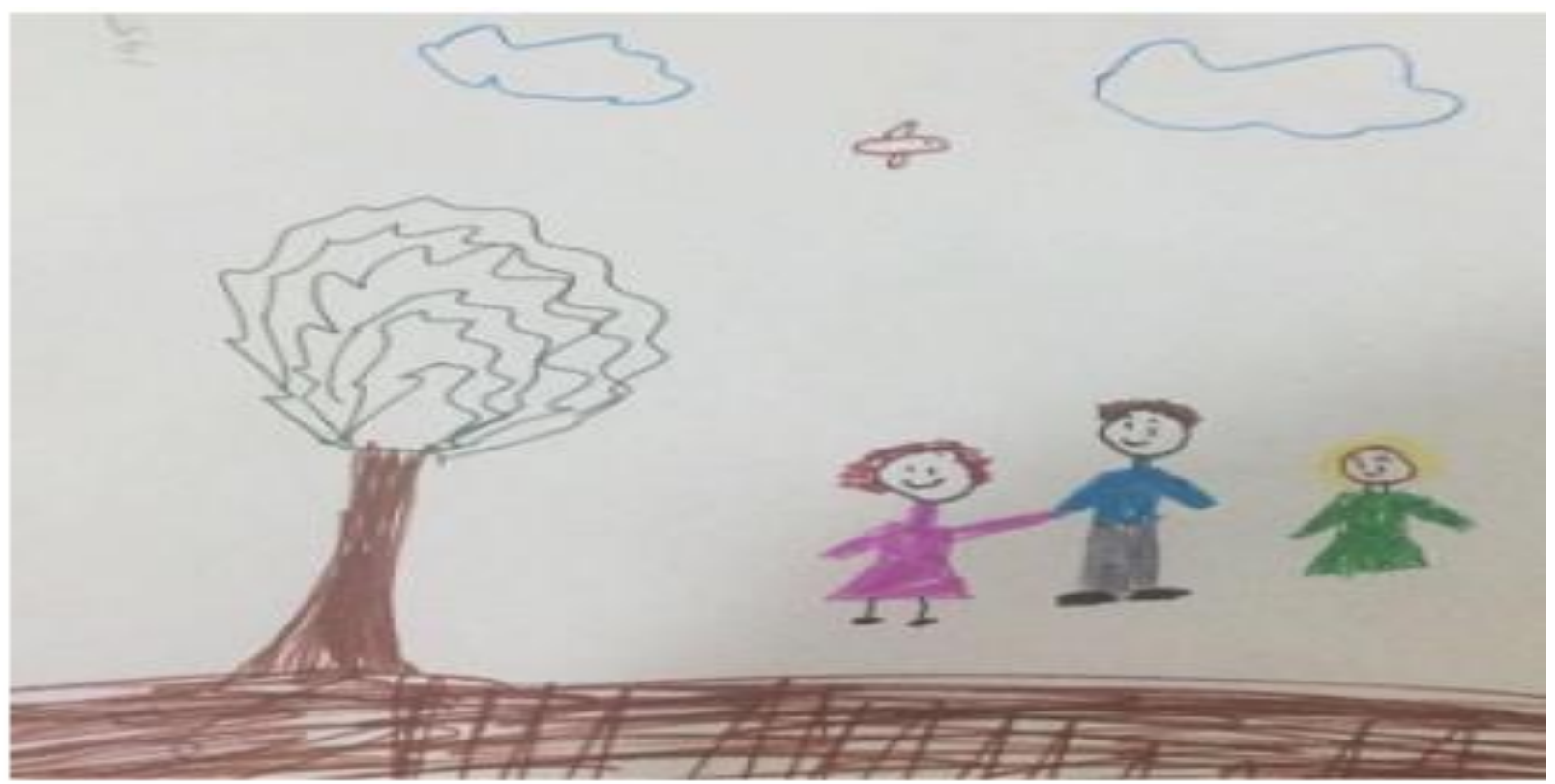

Resim 3. (Kod 195) "Hastaneye babamla gelmek istiyorum, ama serviste babaların kalması yasak. Serviste bizimle ilgilenen sarı saçlı çok sinirli bir hemşire var."

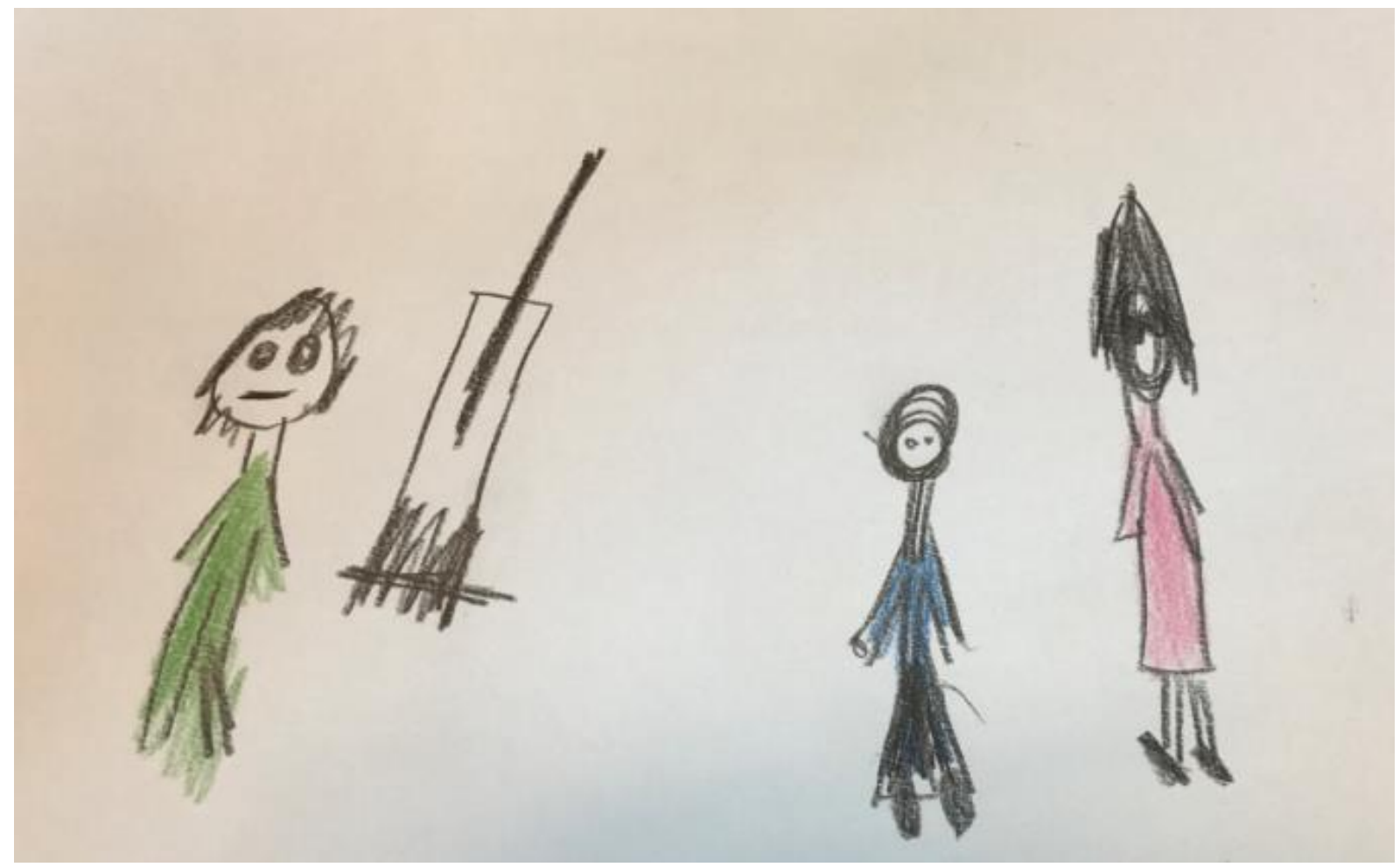

Resim 4. (Kod 230) "Hemşire ve iğne çizdim. Hemşire deyince aklıma iğne geliyor, hemşire odaya girdiğinde ağllyorum" 


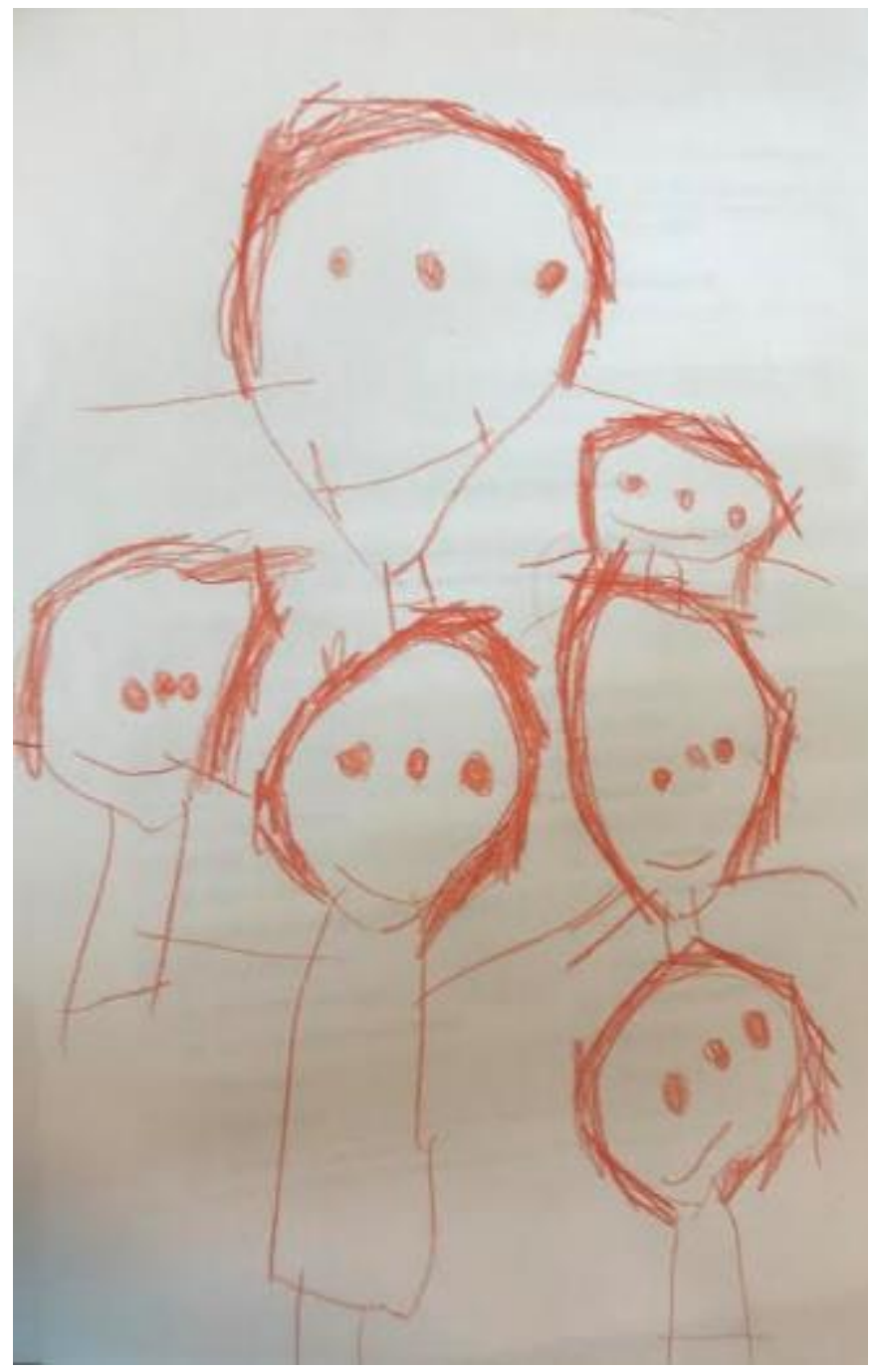

Resim 5. (Kod 298): "Hastanede hemşire ve doktorlar. Hemşireler kız, büyük çizdiğim erkek olan da doktor"

\section{Tartışma}

Yetişkinlere göre duygularını sözlü olarak yeterince ifade edemeyen çocukların resim çizerek psikolojik durumlarını, kişilerarası ilişkilerini, çeşitli duygularını ve iç dünyalarını yansıttıkları $5,8,12$, hemșirelerin çocukları tanımak için resim çizme yöntemini kullanması önerilmektedir16,17.

Araştırmaya katılan çocukların \%76.1'inin hemşireyi resimlerinde insan figürü ile ve çoğunluğunun (\%85.5) kadın olarak çizdiği belirlenmiştir. Canbulat ve ark. (2012) ${ }^{13}$ 'nın yapmış olduğu bir çalışmada, çocukların \%57.8'inin hemşireleri kadın figüründe çizdiği saptanmıştır. Çocuklardan biri hemşire ve doktor çizdiği resimde (Şekil 5) "hastanede hemşire ve doktorlar var. Hemşireler kız, büyük çizdiğim erkek olan da doktor" şeklindeki açıklaması hemșirelik mesleğinin kadınlara özgü bir meslek olarak algılandığını göstermektedir. Hemșirelerin daha çok kadın figüründe çizilmesinin nedeni ülkemizde halen çalışan kadın hemşire sayısının fazla olması ve çocukların daha çok kadın hemşirelerle karşılaşıyor olması ile açıklanabilir.

Alan literatüründe çocukların altı yaşından itibaren çevresinde gördügü şeyleri resme aktarmayı becerdiği, yedi yaşından itibaren uzamsal derinlikleri, hareket ve renkleri daha doğru aktarabildiği belirtilmektedir. ${ }^{9} \mathrm{Bu}$ araştırmada gelişimsel düzeyi göz önünde bulundurularak okul öncesi (3-6 yaş) ve okul yaş grubu (7-12 yaş) şeklinde gruplandırılan çocuklarda 
hemşire algıları açısından fark olmadığı belirlendi. Projektif bir yöntem olarak kabul edilen resim çizdirme yöntemi çocukların duyguları ve algılarını değerlendirmek için psikologlar tarafında sık kullanılmaktadır.5,9 Resimleri daha iyi anlamak için çocuğun farklı yaşlarda kendini ifade etme şekillerini ve resimde yansıttığ gelişimsel özellikleri bilmek gerekir. Çocuğun gelişimsel özelliklerini, resimde yansıttığı özellikler ile Gross ve Haynes (1998) ${ }^{18}$ çocuklarla resim yoluyla sözlü iletişimi daha etkili sağlayıp sağlamadığını incelemek için yaptıkları ardışık çalışmalarda, resim çizmenin çocukların iletişim becerilerini, duygu ve algılarını daha iyi yansıttığını bildirmektedir. Yalnızca sözlü iletişim kurulan çocuklar ile resim çizdirerek iletişim kurulan çocukları inceledikleri çalışmada resim çizen çocukların daha çok șey ifade ettiği bulunmuștur.

Hastaneye yatmanın çocukları korkuttuğu, hoş olmayan deneyimlere ve kontrol duygusu kaybına yol açtığı bildirilmektedir. Akut hastalıklarla yatan çocuklar için bilinmeyenlerden kaynaklı korkuların, kronik hastalarda ise önceden yaşanan olumsuz travmaların ve invazif girişimlerin stres yaratacağl öngörülmektedir.1,5 Çalışma grubumuzdaki çocukların kronik (\%57.6) veya akut hastalık (\%42.4) nedeni ile hastanede yatıyor olmalarının hemşire algılarını etkilemediği saptandı. Şen Beytut ve ark. $(2009)^{5}$ kronik hastalığı olan çocukların \%61.5'inin, akut hastalığı olan çocukların ise \%58.8'inin hastaneyi olumsuz algıladığını, hastane imajı açısından her iki grup arasında istatistiksel olarak anlamlı fark olmadığını saptamıştır. Çocuklar hemşireler ile hiç karşılaşmadan hemşireler ile ilgili fikir sahibi olabilmektedir. Bunun nedeni toplumda hemşireyi iğne yapan kişi olarak çocuğu korkutmak için tehdit unsuru olarak göstermesi olabilir.

Araştırma grubundaki çocukların anne ve babalarının öğrenim durumlarının hemşire algılarını etkilemediği belirlendi. Literatürde çocuğun aile ortamı, anne baba eğitim düzeyi, hastaneye yatmaya hazırlanmanın etkili olduğu bildirilmektedir. Eğitimli ebeveynlerin çocuklarını hastaneye yatmaya daha iyi karşılaştırmak çocuğu daha iyi anlamayı sağlayacaktır. Ayrı bir uzmanlık gerektiren bir alan olması nedeniyle çocukların resimlerde yansıttığı gelişim özelliklerine göre irdeleme yapılması oldukça zordur. $\mathrm{Bu}$ çalışma kapsamında çocukların çizdiği resimlerde hemşireyi nasıl yansıtmak istediğine yönelik açıklamalar çocukların kendilerine yaptırılmıştır.

hazırlaması beklenmektedir.1,5 Çocukların \%66.3'ü resimlerinde hemşireleri olumlu (sevilen, iyileştiren, kurtaran, oyun oynatan, yardım edici, güler yüzlü, iyi insan, beyaz giyinir, çocukları seven, çiçeğe benzeyen, melek, kahraman gibi) algılayarak çizmişti. Elinde zürafa ile gezen güler yüzlü bir hemşire ve bir yıldız çizen (Şekil 1) çocuğun "hastanede kendini güvende hissettiğini ve huzurlu olduğunu" ifade etmesi iletişimin ne kadar önemli olduğunu yansıtması açısından oldukça dikkat çekicidir.

$\mathrm{Bu}$ araştırmanın hemşireler açısından üzerinde durulması gereken en çarpıcı sonucu çocukların 1/3'ünün (\%33.7) azımsanmayacak bir oranda hemşireleri olumsuz (iğne yapan, can acıtan, ağlatan, korkutan, kızgın) algıladığına dair sonuçtur. Çocuğun (Şekil 3) "serviste bizimle ilgilenen sarı saçlı çok sinirli bir hemşire var" veya hemşire ve enjektör çizen (Şekil 4) çocuğun "hemşire ve iğne çizdim. Hemşire deyince aklıma iğne geliyor, hemşire odaya girdiğinde ağllyorum" şeklindeki açılklaması dikkat çekmektedir. Durualp ve ark. $(2012)^{2}$, çocukların \%75'inin hemşirelerin iğne yaptığını, Ünal ve ark. (2002)19'nın yaptığı çalışmanın sonucunda ise çocukların \%22'sinin hemşirelerin iğne yaptığını bildirdiğini saptamıştır. Hastaneye yatan çocukların zihinlerinde enjeksiyon ağrılı ve korkutucu işlemlerden biri olarak yer almaktadır. Hemşireyi iğne yapan kişi olarak çocuğu korkutmak için tehdit unsuru olarak göstermek, çocukların hemşireleri algılamasında olumsuz etki yarattığı bilinen bir gerçektir.

Çocuklar duygularını anlatmada çoğu zaman zorlanırlar. Çocuklarla çalışan hemşireler, çocuğun erişkinden farklı olduğunu bilmeli, gelişim düzeyine uygun iletişim tekniklerini kullanabilmelidir. Kolay ve keyifli bir yöntem olan resim çizdirme ile 
çocukların hemşire ve diğer sağlık profesyonellerinden beklentileri, hastane ve tedaviye ilişkin korku ve kaygıları belirlenebilir. Çocuk anlaşıldığını hissettiğinde güven duygusu artar, kaygıları azalır ve iyileșme süreci kısalır.

\section{Sonuç ve Öneriler}

Çocukların çoğunlukla hemşireyi kadın olarak algıladığı ve 1/3'ünün hemşireyi olumsuz algıladığı belirlendi. Çocukların yaşı, cinsiyeti, hastanede yatma nedeni ve ebeveynlerinin eğitim durumu gibi değişkenler hemşire algılarını etkilememektedir.

Çocuklar duygularını anlatmada çoğu zaman zorlanırlar. Çocuklarla çalışan hemşireler, çocuğun erişkinden farklı olduğunu bilmeli, gelişim düzeyine uygun iletişim tekniklerini kullanabilmelidir. Kolay ve keyifli bir yöntem olan resim çizme ile çocukların hemşire ve diğer sağlık profesyonellerinden beklentileri, hastane ve tedaviye ilişkin korku ve kaygıları belirlenebilir. Çocuk anlaşıldığını hissettiğinde güven duygusu artar, kayglları azalır ve iyileşme süreci kısalır.

\section{Kaynaklar}

1. Çavuşoğlu H. Çocuk sağlığı hemşireliği I (Genişletilmiş 9. baskı). Sistem Ofset Ankara, 2008: 47-86.

2. Durualp E, Çiçenoğlu $S$, Mümünoğlu S, Kalkanlı G, Altuntaş Z. Hastanede yatmış olan okul öncesi dönem çocuklarının yaptıkları resimlerin incelenmesi. Ĕgitim ve Öğretim Araștırmaları Dergisi 2012; 1(3):249-260.

3. Armstrong FD. Neurodevelopment and chronic illness: mechanisms of disease and treatment. Ment Retard Dev Disabil Res Rev 2006;12(3):168173.

4. Er M. Çocuk, hastalık, anne-babalar ve kardeşler. Çocuk sağliğı ve hastallkları dergisi 2006; 49:155168.
5. Şen-Beytut D, Bolışık B, Solak U, Seyfioğlu U. Çocuklarda hastaneye yatma etkilerinin projektif yöntem olan resim çizme yoluyla incelenmesi. Maltepe Üniversitesișirelik Bilim ve Sanat Dergisi 2009;2(3):35- 44.

6. Goodman RF. Children with chronic illness: the interface of medicine and mental health. Child Study Center 2001;5(4):1-9.

7. Stuyck K. Art therapy helps children affected by cancer express their emotions. Oncology 2003;48(12):14.

8. Güven G. Okul öncesi çocuklarının insan ve aile resmi çizimlerinin değerlendirilmesi. (Doktora Tezi), Oya Ramazan, Yayınlanmamış tez, İstanbul, 2009.

9. Malchiodi, CA. Çocukların resimlerini anlamak (Çev. Ed. Yurtbay T). Nobel Tip Kitapevleri; 2013.

10. Yavuzer H. Resimleriyle Çocuk. Remzi Kitapevi; 2003;11-67.

11. Dizman H, Gültekin G, Akyol A. Cocukları tanımada resimlerin önemi. Adli Psikiyatri Dergisi 2005; 2(2):23-30.

12. Malchiodi CA. Using Drawings intervention with traumatized children. Trauma and Loss: Resarch and Interventions 2001; e-1(1).

13. Canbulat N, Kurt AS, Balcı S, Kara S. An analysis of children's thoughts about the nursing profession using the method of having children draw pictures. Health MED 2012;6(6):1900-1905.

14. Okuyucu H. Latent dönemde (6-12 Yaş) çocukların hastane ve hemşireyi algılayış durumlarının incelenmesi. Cocuk forumu dergisi 2003; 6(3):34-38.

15. Park JH. Development of instruments to measure KoreanAmerican and Korean Children's emotional reactions to 
hospitalization. (Doctor of Philosophy), Colorado, 2004.

16. Artut K. Okul öncesinde resim eğitimi. Ankara: Anı Yayıncılık, 2007.

17. Schirrmacher R. Art and creative development for young children (4th edition). USA: Delmar Thomsan Learning, 2001.
18. Gross J, Haynes H. Drawing facilitates children's verbal reports of emotionally laden events. J Exp Child Psychol 1998; 4:163-179.

19. Ünal AS, Akbayrak N, Uluğ A. Çocukların hemşirelik hakkındaki düşünceleri. Hemşirelikte araştırma geliştirme dergisi 2002;4(2):60-66. 